7. Анатолій Скиба: проспект виставки творів / Авт. Т. Удіна. Чернівці, 1970.

8. Анатолій Георгійович Скиба : каталог / Авт. К. Валігура. Чернівці, 1980. 48 с. 1998. 128 c.

9. Митці Буковини: Енцикл. довід. / Авт.-упоряд. Т. Дугаєва, І. Міщенко. Т.1. Чернівці : Золоті литаври,

10. Іван Салевич. Скульптура: каталог / Вст. ст., уклад. І. Міщенко. Чернівці : ДрукАрт, 2010. 20 с.

\title{
References
}

1. The meridian of the heart. O. Jaghodovsjka (Ed.). (1998). Chernivci: Bukrek [in Ukrainian].

2. Antonina Tebenjkova. (1973). Chernivci [in Ukrainian].

3. Mishchenko, I. (2010). Ceramics in the works of Bukovinian artists of the 1980s and 2000s. Art Studies Studios, 2 (30), 42-49 [in Ukrainian].

4. Bukovina Art: Catalog. (2004). Chernivci [in Ukrainian].

5. Dughajeva, T. (2002). Sculptor, Doctor of Medicine Opanas Shevchukevych. Chernivci: Zelena Bukovyna [in Ukrainian].

6. Jurij Dzhybrajev. T. Udina, \& Je. Udin (Eds.). (1970a). Chernivci [in Ukrainian].

7. Anatolij Skyba. T. Udina. (Ed.) (1970b). Chernivci [in Ukrainian].

8. Valighura, K. (1980). Anatolij Gheorghijovych Skyba. Chernivci [in Ukrainian].

9. Bukovina Artists. T. Dughajeva, \& I. Mishchenko. (1998). Vol. 1. Chernivci: Zoloti lytavry [in Ukrainian].

10. Ivan Salevych. Sculpture: Catalog. I. Mishchenko (Ed.). (2010). Chernivci: DrukArt [in Ukrainian].

Стаття надійшла до редакції 23.06.2019 р.

УДК: 73.071.1(=161.2)(100)"19"

\author{
Одрехівський Володимир Васильович \\ кандидат мистецтвознавства, професор, \\ ректор Львівської національної академії мистецтв \\ ORCID 0000-0001-5905-4781 \\ studio@odre.com.ua \\ Одрехівський Василь Володимирович \\ кандидат мистецтвознавства, магістр, \\ старший викладач кафедри \\ монументально-декоративної скульптури \\ Львівської національної академії мистецтв \\ ORCID 0000-0001-9462-230X \\ vasyl.odrekhivskyy@gmail.com
}

\section{КОНЦЕПТУАЛЬНО-ПЛАСТИЧНІ АСПЕКТИ ПОЛІХРОМІЇ ТА КІНЕТИЗМУ В УКРАЇНСЬКІЙ СКУЛЬПТУРІ XX СТОЛІТТЯ}

\begin{abstract}
Мета статті - виокремити та проаналізувати творчість українських митців, які жили та працювали за межами України у XX столітті і в своїй творчості застосовували новаторські скульптурні засоби вираження. Методологія. Дослідження базується на мистецтвознавчому методі, комплексному поєднанні методу художнього аналізу, класифікації та абстрагування, фактологічно-описового, порівняльно-історичного і структурно-типологічного методів. Наукова новизна статті полягає у розкритті аспекту образно-пластичної трансформації в українській скульптурі XX століття, акцентуючи на концептуальних проблемах кольору та руху. Систематизація обраного матеріалу дозволяє сформувати новий погляд на українську пластику у її нерозривній єдності зі світовими мистецькими тенденціями. Висновки. В результаті дослідження продемонстровано новаторські пластичні пошуки українських скульпторів XX століття, які мали змогу втілити свої авторські концепції за межами України. У творчості О. Архипенка, К. Мілонадіса, М. Урбана, А. Перейми, Р. Костинюка, М. Дзиндри підтверджено наявність та з'ясовано особливості концептуально-пластичних аспектів поліхромії та кінетизму, асамбляжу та інсталяції, що, в свою чергу, доводить факт інтеграції цього сегменту української культури у світовий мистецький процес XX століття. Підтверджено, що творчі винаходи О. Архипенка стали вагомим джерелом натхнення для наступних генерацій українських скульпторів.
\end{abstract}

Ключові слова: скульптура, композиція, поліхромія, кінетизм, інсталяція.

Одрехивский Владимир Васильевич, кандидат искусствоведения, профрессор, ректор Львовской национальной академии искусств; Одрехивский Василий Владимирович, кандидат искусствоведения, магистр, старший преподаватель кафедры монументально-декоративной скульптуры Львовской национальной академии искусств

Концептуально-пластические аспекты полихромии и кинетизма в украинской скульптуре XX века

Цель статьи - выделить и проанализировать творчество украинских художников, которые жили и работали за пределами Украины в XX веке и в своем творчестве использовали новаторские скульптурные средства выражения. Методология. Исследование базируется на искусствоведческом методе, комплексном сочетании метода художественного анализа, классификации и абстрагирования, фрактологически-описательного, сравни-

() Одрехівський В. В., 2019

(С) Одрехівський В. В., 2019 
тельно-исторического и структурно-типологического методов. Научная новизна статьи заключается в раскрытии аспекта образно-пластической трансформации в украинской скульптуре $\mathrm{XX}$ века, акцентируя на концептуальных проблемах цвета и движения. Систематизация выбранного материала позволяет сформировать новый взгляд на украинскую скульптуру в ее неразрывном единстве с мировыми художественными тенденциями. Выводы. В результате исследования продемонстрировано новаторские пластические поиски украинских скульпторов XX века, которые могли воплотить свои авторские концепции за пределами Украины. В творчестве А. Архипенко, К. Милонадиса, М. Урбана, А. Переймы, Р. Костинюка, М. Дзындры подтверждено наличие и выяснены особенности концептуально-пластических аспектов полихромии и кинетизма, ассамбляжа и инсталляции, что, в свою очередь, доказывает факт интеграции этого сегмента украинской культуры в мировой художественный процесс XX века. Подтверждено, что творческие изобретения А. Архипенко стали весомым источником вдохновения для будущих поколений украинских скульпторов.

Ключевые слова: скульптура, композиция, полихромия, кинетизм, инсталляция.

Odrekhivskyi Volodymyr, Ph.D. in Art Studies, Professor, Rector of the Lviv National Academy of Arts; Odrekhivskyi Vasyl, Ph.D., Master's, Senior Lecturer of the Department of Monumental-Decorative Sculpture of the Lviv National Academy of Arts

Conceptual and plastic aspects of polychromy and kineticism in Ukrainian sculpture of the XXth century

The purpose of the article is to highlight and analyze the artworks of Ukrainian artists who lived and worked outside Ukraine in the XX century and used innovative sculptural means of expression in their work. Methodology. The study is based on the art history method, a complex combination of the method of artistic analysis, classification, and abstraction, factual-descriptive, comparative, historical, and structural-typological methods. The scientific novelty of the article is the disclosure of the aspect of image-plastic transformation in the Ukrainian sculpture of the XX century, emphasizing the conceptual problems of color and movement. The systematization of the selected examples allows us to form a new look at Ukrainian sculpture in its inseparable unity with world artistic trends. Conclusions. As a result of the research, innovative plastic researches of Ukrainian sculptors of the XX century, which could embody their author's concepts outside of Ukraine, were demonstrated. The works of A. Archipenko, K. Milonadis, M. Urban, A. Pereima, R. Kostinyuk, M. Dzyndra confirmed the existence and clarified the features of the conceptual-plastic aspects of polychromy and kineticism, assemblage and installation, which, in turn, proves the fact of integration of this segment of Ukrainian culture in the art-world process of the XX century. It was confirmed that A. Archipenko's creative inventions became a significant source of inspiration for future generations of Ukrainian sculptors. If in states where Catholicism was prevalent, it was a circular sculpture that was the main imaginative in the religious sphere, then the requests of Orthodox Christianity sent artistic expression into a two-dimensional imagery space. Kievan Rus was dominated by the Byzantine icon painting tradition, which actively developed painting (including murals) and mosaics that are directly related to the use of color. This influenced the whole further course of the development of Ukrainian art and, undoubtedly, on a certain subconscious level also influenced the polychrome experiments of $O$. Arkhipenko and other sculptors of the twentieth century, despite the fact that they were engaged in a kind of art, which in its traditional expression was relatively rarely foreseen. use of color and its conceptual and expressive aspects.

Key words: sculpture, composition, polychromy, kineticism, installation.

Актуальність теми дослідження. Сучасні інтеграційні процеси, глобалізація, активне входження вітчизняної мистецької системи у світовий культурний простір - ті явища, які уніфікують критерії аналізу української скульптури із зарубіжною пластикою і підсилюють актуальність її розгляду в контексті утвердження української культурної ідентичності. У даній статті розглядається питання про те, яким чином українські митці започатковували новаторські підходи у тривимірному творенні скульптури.

Актуальність дослідження полягає й у тому, що тут аналізується творчість таких маловідомих українському мистецтвознавству скульпторів як Ака Перейма, Рон Костинюк, Михайло Урбан, а також напрацювання митців, чия творчість потребує переосмислення з огляду на культурологічні виклики нашого часу: Олександр Архипенко, Михайло Дзиндра, Костянтин Мілонадіс.

Аналіз останніх досліджень і публікацій свідчить про те, що проблеми образотворення у скульптурі перебувають у сфрері зацікавлення багатьох авторів. Зусиллями мистецтвознавців та дослідників було видано чимало монографрій, каталогів, антологій, збірників статей, було опубліковано наукові праці та дослідження на тему української скульптури $\mathrm{XX}$ століття. Серед тих, які напряму стосуються теми нашої статті, варто виділити теоретичні пошуки О. Голубця [1], В. Качуровського [3], М. Маричевського [5], М. Протас [10], О. Лагутенко [4], Б. Певного [9], С. Гординського [12], Г. Новоженець [8], Б. Мисюги [13], Г. Стельмащук [14], О. Федорука [15, 16], Р. Яціва [2, 11]. Перелічені автори розглядають українську скульптуру XX століття у широкому розрізі образно-пластичних проблем, однак комплексних досліджень присвячени кінетичній та поліхромній скульптурі проведено не достатньо.

Водночас, серед переліку досліджень на окреслену тематику варто зазначити теоретичні праці й самого О. Архипенка «П'ятдесят творчих літ, 1908-1958» [17], у яких скульптор вербалізує та грунтовно систематизує свої творчі концепції.

Мета статті - виявити і проаналізувати концептуально-пластичні аспекти поліхромії та кінетизму в українській скульптурі XX століття.

Виклад основного матеріалу. Насамперед, у контексті нашого дослідження варто зробити стислий екскурс в історію української скульптури. При розгляді мистецтва Київської Русі, як одного 3 періодів з найбільшим піднесенням в українській історії, з'ясовується, що тривимірна скульптура була обмеженою у своїх просторових можливостях і проявилась здебільшого у дерев'яних та кам'яних сте- 
лах релігійного призначення та плоских рельєфах. Якщо у державах, де був поширений католицизм, саме кругла скульптура була основним зображальним засобом у релігійній сфері, то запити православного християнства спрямовували мистецьке вираження у двовимірний зображальний простір. У Київській Русі домінувала візантійська іконописна традиція, завдяки якій активно розвинулось малярство (зокрема фрески) та мозаїка, які безпосередньо пов'язані з використанням кольору. Це вплинуло на весь подальший хід розвитку українського мистецтва і, безперечно, на певному підсвідомому рівні вплинуло й на поліхромні експерименти О. Архипенка та інших скульпторів XX ст., незважаючи на те, що вони займались видом мистецтва, який у своєму традиційному вияві відносно рідко передбачав використання кольору і його концептуально-виражальних аспектів.

У даному контексті буде справедливим твердження про те, що саме творчість Олександра Архипенка маркує виразний перехід української скульптури на зламі XIX-XX ст. з одного стану у якісно інший, оскільки він кинув рішучий виклик традиційному розумінню пластики і став правдивим джерелом експериментаторства у мистецтві у XX століття. Митця можна по праву вважати унікальною особистістю, яка увібрала і матеріалізувала максимальну можливу кількість аспектів творчості: скульптуру від реалістичного до кубістичного трактування, поліхромію тривимірних фрорм, малярство, інженерію, новітні матеріали, оперування ілюзією позитивного та негативного простору, теоретичнофрілософські пошуки, у яких він довів логічність своїх винаходів. Архипенко створив різноманітну та провокативну, як на його час, пластичну мову в результаті тісного зв'язку з мультикультурним контекстом Західної Європи та США, у якому він перебував більшу частину свого життя. Влучно охарактеризовує митця і його фундаментальний вклад для подальшого розвитку скульптури О. Федорук: «Наш геніальний земляк Олександр Архипенко омріював візуально системну кінетичну пластику через архипентури, модератори, порожнини, через освітлений зсередини пластик, через переконання ствердити гармонію нового мистецтва, він, Архипенко, немовби готував ґрунт для сучасного мистецтва, немовби прискорив творчою уявою з'яву Contemporary art» [16, 245].

Відтак, можемо простежити певний зв'язок високого розвитку живопису, мозаїки та іконописання ще з часів Київської Русі з тим, що саме український скульптор на початку XX ст. чи не найбільше зпоміж відомих скульпторів окресленого періоду (у світовому контексті) проявив себе у активному використанні кольору. Ранні поліхромні об'ємні композиції митця «Медрано І» (1912), «П'єро-карусель» (1913) і більш пізні «Вертикальна фрігура» (1935), «Архітектурна фрігура» (1950) та інші яскраво демонструють практики митця, у яких він поєднує пластику форми з кольоровими плямами. Як стверджує митець, «нова кольорова скульптура - це нова естетика і нова техніка, які поєднують колір з фрормою, їх взаємопереплетення, змішання, домінування кольору над фрормою чи навпаки, їхня гармонія, контраст і ритм - усе це можна використовувати при розв'язанні символічних чи стилістичних проблем» $[17,26]$.

У живописній практиці О. Архипенко виходить за межі звичної двовимірності малярства і надає йому фрізичного об'єму. Таким чином з'являється нова категорія у творчості митця - «скульптоживопис», у якій, руйнуючи звичні межі, поєднуються два види мистецтва. Водночас, тут є відмінність від звичайної багатоколірної скульптури періоду готики, ренесансу чи бароко. Митець вважав «скульпто-живопис» новим видом мистецтва завдяки специфічним взаємозалежностям рельєфу, увігнутих та перфорованих фрорм, кольорів та фрактури, які утворювали конструкції в межах панно [17, 23]. Одними з найвідоміших творів «скульпто-живопису» $є$ «Медрано II» (1913-1914), «Жінка перед дзеркалом» (1914), «Жінка на колінах» (1918-1919), «Овальна фрігура» (1957), «Клеопатра» (1957). Ми бачимо, що усі Архипенкові багатоколірні роботи, чи то рельєфні чи об'ємні, доповнюють його переконання про те, що природа не лише не відділяє фрорму від кольору, а об'єднює їх у нескінченній кількості варіацій. Це сполучення підсилює абстрактну експресивність, яка допомагає виразити духовне чи символічне.

Виразним пластичним почерком митця було активне використання увігнутих та наповнених фрорм, за допомогою яких він оперував ілюзією світло-тіні. Деконструювання натуралістичної фрорми відбувалось за рахунок інверсії позитивних та негативних елементів. Це трактування об'ємів пронизує усі напрями творчості митця - від круглої скульптури, серед якої «Статуя» (1916), «Геометрична сидяча жінка» (1920), «Прославлення краси» (1925) до «скульпто-живопису» та рельєфів.

О. Архипенко активно використовує у скульптурі новітні матеріали, які з'являються з часом. Він створює роботи «Сидяча фрігура» (1947), «Спрямована вперед» (1947) з прозорого плексигласу (полімерні смоли), всередині яких використовує електичне освітлення. Це вкотре розширює палітру зображальних засобів митця. Він вважав, що якщо елемент здатний виразити зовнішню духовну та естетичну цінність, то потрібно докласти зусиль, щоб добитись від нього очікуваного результату, ефекту, символічного значення, краси чи духу. [17, 19].

Ще одним винаходом митця вважається робота з простором, а точніше те, що він вирівняв у своїй важливості конкретно-матеріальну структуру твору мистецтва і простір навколо. 3 того моменту вони стали рівнозначні. О. Архипенко використовує ажур замість реальної форми у роботах «Та, що йде» (1914-1915), «Жінка, яка розчісує волосся» (1915), «Статуя» (1915), «Сидяча чорна увігнута» (1916) тощо. У тій чи іншій мірі ці підходи вплинули на способи організації простору у скульптурі, зо- 
крема, це простежується у роботах американських митців течії мінімалізму, ленд-арту та інсталяції наступних десятиліть.

Що стосується проблеми руху в мистецтві, то вона була завжди у сфері дослідження художників. Нею активно займалися італійські футуристи на початку XX ст., ще раніше, у XIX ст., у мистецтві фотографії фріксацією та аналізом руху займався Е. Майбрідж. О. Архипенка по праву можна вважати винахідником, який вивів динамізм зі сфери символічної візуалізації та ілюзорності у сферу фрізичного та матеріального. Одним з результатів його експериментів було створення пристрою, якому митець дав назву «Архипентура» (1927) - це механічний апарат з металу, у який було інтегровано 110 полотен із зображеннями. Вони обертались на циліндричних стержнях і в сукупності фрормували нову, постійно змінну площинну композицію. Таким чином утворювався «кінетичний живопис», який уособлював переконання Архипенка про те, що світ існує у невпинному русі і всі елементи у ньому взаємопов'язані. Винахід митця був радикальним для мистецького світу, оскільки був унікальною єдністю живопису, часу і простору. «Архипентура» $€$ однією з найдосконаліших форм модерного мистецтва, оскільки тут вдалося у повній мірі зануритись у проблему динамізму, яка до цього часу залишалась нерозв'язаною у статичному живописі.

Скульптор-практик закріплює та підсилює свою творчу роботу концептуальними роздумами про неї у книзі «Архипенко О. П'ятдесят творчих літ. 1908-1958» [17, 2]. Український мистецтвознавець С. Годинський узагальнює ідейну позицію митця: «Теорія космічного динамізму - теорія вищої організуючої сили, яка управляє всім - від людини і до рослин і мінералів. Він дивиться на творення як на особливий стан енергії, де планетарні сили взаємодіють з нашими клітинами в нескінченній еволюції. Людина дістає енергію та ідеї від космічних творчих сил і підносить свої власні творчі можливості до вищого ступеня, де єднаються дух і матерія» [17, 2].

Ще одним українським митцем, творчість якого тяжіла до абстрактних форм є Михайло Урбан. Скульптор народився на Галичині у 1928 р. і, виїхавши до США, провів більшу частину свого життя у Чикаго. Художник почав свій мистецький шлях з живопису і лише пізніше перейшов до тривимірної пластики.

В М. Урбана високо розвинене відчуття кольору і об'ємної форми у скульптурі, саме тому йому вдалось настільки ефективно синтезувати ці два види мистецтва. Митець використовує для створення скульптури переважно метал та дерево і його композиції втілюють ідеї від абстрактного до фрігуративно-органічного характеру. На думку дослідників, митець проявляє окрему яскраву індивідуальність, спираючись на свою міцну культуру естетики. Можна б розглядати більшу частину його творів у дуже широких рамках загального розуміння конструктивізму [3, 85-86].

Скульптури М. Урбана володіють якостями об'ємної просторовості, де цілість і єдність фрорм сприяють врівноваженості композицій з усіх можливих ракурсів. Митець пропонує глядачеві насичені конфігурації ліній і фрорм, які «запрошують» до кругового огляду. Навіть менші Урбанові скульптури в дереві містять у собі згущену композицію. Всі вони проявляють ритмічний рух опуклих та увігнутих, позитивних та негативних фрорм. Тут справжнє багатство бароккового динамізму [3, 87].

Одними з найзначніших творів митця є «Передвиборча мрія» (1967-1968), «Єсрод» (1968), «Білий рельєф» (1968), «Пульсуюча форма» (1969), «Паралельний контрапункт» (1971), «Принада» (1971), «Без назви» (1976), «Структура з трьома негативними прямокутниками» (1972). У творчості М. Урбана можна простежити тісний зв'язок з тенденціями американської скульптури мінімалізму 1960-1970-х рр., де протиставляються лапідарні горизонтальні та вертикальні форми. У пріоритеті пластичної зацікавленості митця перебуває архітектоніка монументальних форм, їхня монолітність та цільність. Урбан не обмежується лише формою скульптури, а задіює фрормальні геометричні об'єми, почленовані кольоровими площинами, з яких і походить символізм образів. У цих лаконічних візерунках і прочитується дух українських коренів скульптора. Михайло Урбан, будучи у контексті сучасного мистецького світового досвіду, адаптовує особистісний тип мислення у пластиці.

Важливе місце в українському мистецтві зарубіжжя посідає Костянтин Мілонадіс. Митець народився на Полтавщині у 1926 р., а у 1951 р. емігрував до Чикаго (США). Серед українських митців ще ніхто так глибоко не досліджував рух та динаміку засобами скульптури. Твори митця можна вважати унікальними, оскільки вони уособлюють дух епохи в якій технологічність та індустріалізація інтегруються у всі сорери життя. «В історії мистецтва зустрічались фракти залучення до творів рухомих елементів, однак саме в XX столітті митці зайнялися свідомо і серйозно проблемою фактичного руху як естетичного елементу й довели до його успішного втілення у мистецькій творчості. Динамізм, замість попередньої стабільності, став головною характеристикою сучасної скульптури» [7, 3].

К. Мілонадіс створює цілком нові фрорми, уникаючи прямих зображальних засобів, які б нагадували антропоморфні форми. В основі його мистецтва лежить ідея про те, що рух, час та простір $\epsilon$ принциповими властивостями всього сущого на Землі та у Всесвіті. Як стверджує В. Качуровський про творчість митця: «Увесь наш світ складається більше з процесів змін, аніж з статичного буття. Всі форми мистецького прояву також містять у собі, до певної міри, елементи руху: танець, музика, поезія та все образотворче мистецтво всіх віків та напрямків» [7, 3].

Легкі, практично позбавлені відчутної матеріальності, конструкції митця є протилежними до традиційного розуміння скульптури як масивного об'єму, сформованого у просторі. Мінімалістичні лінії 
його композицій лише обмежують, фіксують простір, не маючи на меті його заповнювати і це суттєво виділяє творчість К. Мілонадіса з-поміж інших скульпторів. Концепції митця уособлюють роботи «Підкорювач хвиль» (1964), «Кінетична конструкція 2» (1978), «Конструкція з пружин №7» (1978), «Кінетична конструкція» (1979), «Без назви» (1981). Кожна скульптура резонує з навколишнім средовищем, оскільки є чутливою до найменших вібрацій, а ідея єдності всього сущого виразно відчитується у роботах митця, коли різні об'єкти взаємодіють, здійснюючи вплив один на одного. Як стверджує О. Федорук: «Засади динамізму визначають основні критерії існування кінетичної скульптури, яка заперечує розуміння скульптури як статичного об'єму в просторі. Сфрормовану масу замінили у кінетичній скульптурі лінії рухомих конструкцій, матеріальна маса поступилася місцем і була зведена до мінімалізму елементарної площини або лінії. Водночас нові просторові відношення зумовили потребу в кінетизмі, дали відчуття пружності, легкості, мінливості в часі» $[15,69]$. К. Мілонадіс зумів поєднати скульптуру та фізику, де рівновага і баланс стають кінцевою метою кожної композиції. Скульптури митця немов утворюють тривимірні рисунки у просторі, які мають легкий та виразний силует з усіх ракурсів.

Важливою у даному контексті дослідження є творчість Аки Перейми, яка закінчила мистецьку школу у США. У багатьох творах А. Перейми можна простежити вплив українського фрольклору і орнаменту писанок. У своїй пластиці скульпторка вдається до радикальної геометризації об'ємів, ії композиції масивні та монолітні. «Їхні абстрактні, дещо підкреслено локалізовано кубічні форми демонструють міць, усталеність, стверджують статичну місткість предмета в просторі. Пластика, що органічно поєднує площинність і об'єм, фактура, визначена гладкою поверхнею металевого міста, підсилюють відчуття стабільності, впевненої організації ритмів» [15, 34]. У монографрії про мисткиню О. Федорук зазначає: «Скульптура А. Перейми генерує рух пошуку і творчого поривання, базується на експерименті матеріалів та фрорм. Ці форми невід'ємні одна від одної, вони можуть існувати лише разом, створюючи поняття чуттєвого, сповненого внутрішньої енергії і притягальної сили об'єму» $[15,39]$.

А. Перейма використовує технології електрозварювання як основний метод для опанування металу. Різні за характером роботи мисткині «Невільник» (1967), «Двоє» (1973), «Без назви» (1973), «Витяте коло», (1974) можна окреслити такими категоріями як асамбляж, інсталяція, кінетична та формально-мінімалістична, абстрактна скульптура з використанням кольору. Образно-осмислена пластика А. Перейми є поетичною, емоційною та наповненою асоціативно-метафоричними алюзіями. «Будучи експериментаторкою з фрормами у просторі, А. Перейма пропонує пластику, сучасну за духом мислення й способом формотворення. Мистецькі пошуки художниці увібрали від сучасних пластичних експериментів деякі аспекти поп-арту, і кінетизм, і фрормотворчі пошуки в галузі геометричної абстракції $[15,54]$.

Важливою у контексті дослідження $є$ творчість маловідомого на Батьківщині митця з Канади Рона Костинюка. Його площинні та просторові композиції мають виразний конструктивістський характер, а мінімалізм пластичного вислову та гранична простота не є причиною збіднення концепції, а навпаки - результатом виважених високо-інтелектуальних рішень та самодисципліни автора.

Р. Костинюк тяжіє до абстрактної пластики з активним використанням насичених кольорів, моделює просторові та структурно-рельєфні геометризовані композиції. Пластичні аспекти ритмів постають у творчості митця, які, через ускладнене поєднання структури фрорми та поліхромованих плям, утворюють візуально-матеріалізовану мелодію у скульптурі. Абстрактні композиції мають здатність формувати багатий асоціативний ряд, який через мінімалістичну, педантично і раціонально згармонізовану композицію, вводить глядача у дистанційований від реальності простір суб'єктивного трактування митцем природи та навколишнього середовища. Р. Яців вважає, що «принцип, за яким найпростіший геометричний елемент «вибудовував» абстрактний лад композиції, відрізнив Костинюка від художників оп-арту чи концептуалістів своєю "морфогенетичною доктриною фрорми". В цій групі творів комбінаторика розташування базового модуля була зведена до таких структурних комплексів, які виявляли проміжні стадії розвитку біосистеми в еквіваленті естетичних інтегралів» $[11,14]$.

Скульптор родом з Львівщини Михайло Дзиндра почав активне творче життя емігрувавши у 1944 р. через Західну Європу до США. Митець працював виключно у сфрері абстрактної скульптури. Протягом життя М. Дзиндра створив сотні скульптур, понад 800 з яких привіз в Україну в 1990-х роках у збудований за власні кошти музей. Його роботи характеризуються сміливим пошуком композицій, які поєднують виразну фрорму, чіткий силует, колір, різноманітні текстури та ажури. Своєю творчістю М. Дзиндра утверджує свободу від академічних канонів і скеровує своє мистецтво в інше русло. Скульптура митця підкреслює поділ мистецтва на предметне й безпредметне: те, що колись було єдністю у творі мистецтва (живопису, скульптури тощо) - дух і матерія, з часом зазнає різних модифікацій і балансує між матеріальною реальністю і «творчим духом». Просторові експерименти М. Дзиндри максимально віддаляються від реальності, визволяючи «збунтований» дух [2, 213-217] і даючи йому свободу у вільно-текучих фрормах абстрактної скульптури.

Твори, які виразно відображають мистецьку фрілософію М. Дзиндри є «Червоний абстракт» (1969-1973), «Переляканий солдат» (1970-1971), «Гнуті форми» (1976), «Танок» (1977). Кожна із них поєднує якості монументальності, простоти, лаконічності й мінімалізму висловлення. «Спрямування до монументалізації для Михайла Дзиндри є синонімічним закінченості мистецького виразу. Це прагнення 
монументальності скульптор розвиває, стратегічно передбачає появу нової мистецької якості вільної форми» $[13,135]$.

Дослідник Б. Мисюга висловлює думку, що «після кожного “випробування” нової фрорми скульптор вдається до ії “дисципліни”, не втрачаючи при цьому динаміки пластичних зіставлень. Ця “дисципліна”, як правило, має характер монументалізації образу. Так, маніпулюючи матеріальною формою і навколопредметним простором, М. Дзиндра намагається довести риторичне твердження абстракціоністів щодо того, що образність у мистецькому творі залежить в основному від загального пластичного ладу композиції. [...] Прагнення М. Дзиндри до монументального виразу, лаконізм його композиційних рішень, широта пластичного діапазону навіть в межах одного твору - характерні якості мистецького таланту, що роблять його творчість надбанням саме українського мистецтва у його багатовекторних естетичних проекціях» [13, 7]. Багата уява митця проектує асоціативні образи у найсміливіші конструкції об'ємних поліхромованих фрорм, таким чином, досягаючи неабиякої складності та виразності.

Висновки. Олександр Архипенко та його широкий спектр експериментів, від класичних студій до абстрактних пошуків, від «скульпто-живопису» до рухомої «Архипентури» - виявився плідним ґрунтом для творчої праці чималої когорти митців наступних поколінь. Вони продовжили не тільки активізовувати трансформації ідейно-пластичних аспектів скульптури розвиваючи ідеї О. Архипенка, а й створювати свої сміливі винаходи, суголосні тогочасним тенденціям: Михайло Урбан практично всі свої скульптури збагатив і ускладнив кольором, Костянтин Мілонадіс статику замінив рухом, А. Перейма втілила в металі фрормально-мінімалістичні скульптури та асамбляжі. Це одні з тих яскравих прикладів, які демонструють залученість української скульптури до світового мистецького процесу не у ролі наслідувача, а в якості самодостатнього явища з широким діапазоном ідейно-пластичних конфігурацій. Кожен з обраних нами до розгляду митців утверджував позиції української скульптури у світовому мистецтві в другій половині XX ст., розвиваючи глибинні філософсько-естетичні проблеми вищого регістру екзистенційної шкали людини.

Перспективи подальших досліджень пов'язані насамперед з новими іменами скульпторів, які продовжують розвивати винайдені у XX ст. образно-пластичні засоби вираження, а також з поглибленням аналізу творчості згаданих у даній статті митців у іншому розрізі концептуальних проблем.

\section{תimepamypa}

1. Голубець О. М. Мистецтво XX століття: український шлях. Львів : Колір ПРО, 2012. 200 с.

2. Ідеї, смисли, інтерпретації образотворчого мистецтва: українська теоретична думка XX століття : антологія / упоряд. Р. М. Яців. Львів: Льв. нац. акад. мистецтв : Ін-т народознав. НАН України, 2012. Ч. 1. 232 с.: іл.

3. Качуровський В. Скульптор Михайло Урбан // Сучасність. Мюнхен, 1973. № 9. С. 85—92.

4. Лагутенко О. Твори Олександра Архипенка у Києві // Артанія. Київ, 2004. № 6. С. 44-45.

5. Маричевський М. Олександр Архипенко: візія і тяглість // Образотворче мистецтво. Київ, 2005. № 3. C. $38-41$.

6. Михайло Урбан : каталог творів / [авт. тексту Вальтер Р. Мартін]; Укр. ін-т модерного мистецтва. Чикаго, 1973. 16 с.

7. Мілонадіс Костянтин : каталог виставки / текст В. Качуровського. Чикаго: Укр. Ін-т модерного мистецтва, 1973.12 с.

8. Новоженець Г. Образотворче мистецтво української діаспори 1940-1970 років: поліваріантність художнього досвіду. Львів : Кальварія, 2015. 280 с.

9. Певний Б. Майстри нашого мистецтва. Київ: Сучасність, 2005. 432 с.

10. Протас М. О. Українська скульптура XX століття / Акад. мистецтв України; Ін-т проблем сучас. мистецтва. Київ : Інтертехнологія, 2006. 278 с.

11. Рон Костинюк. Одісея кольороформи : кат. вист. / [авт. тексту Р. Яців]. Львів: Нац. музей у Львові ім. А. Шептицького, 2014. 148 с.

12. Святослав Гординський про мистецтво : зб. ст. / упоряд. Х. Береговська. Львів : Апріорі, 2015. 1024

с.: іл.

13. Скульптура Михайла Дзиндри / упоряд. Б. Мисюга. Івано-Франківськ : Лілея-НВ, 2001. 344 с.: іл.

14. Українські митці у світі. Матеріали до історії українського мистецтва XX ст. / авт.-упоряд. Г. Г. Стельмащук. Львів : Апріорі : Львів. нац. акад. мистецтв (Н.-д. сектор), 2013. 520 с.

15. Федорук О. Дивосвіт Аки Перейми. Київ: Веселка, 1996. 142 с.: іл.

16. Федорук О. Перетин знаку: Вибрані мистецтвознавчі статті : у 3 кн./ Ін-т пробл. сучас. мистецтва Акад. мистецтв України. Київ : Інтертехнологія, 2008. Кн. 3: Українська культурологія. Історія та теорія мистецтва. Постаті. Народна творчість. Рецензії. 416 с. : іл.

17. Archipenko A. Archipenko: Fifty Creative Years, 1908-1958. New York : TEKHNE, 1960. 109 p., 292 il.

\section{References}

1. Holubets, O. (2012). The art of the twentieth century: the Ukrainian way. Lviv: Kolir PRO. [in Ukrainian].

2. Yatsiv, R. (2012). Ideas, meanings, interpretations of fine arts: ukrainian theoretical thought of the XX century: anthology. Lviv: Lviv National Academy of Arts, Institute of Ethnology NAS of Ukraine. [in Ukrainian].

3. Kachurovskyi, V. (1973). Sculptor Mykhailo Urban (pp. 85-92). Munich: Suchasnist № 9. [in Ukrainian].

4. Lahutenko, O. (2004). Works by Alexander Archipenko in Kyiv (p.p. 44-45). Kyiv: Artaniia № 6. [in Ukrainian]. 